\title{
Research of the activities of the Khabarovsk regional park named after N.N. Muravyov- Amursky for the provision of services to the population in the field of culture and leisure
}

\author{
Oksana Machkarina, and Svetlana Pankratieva* \\ Far Eastern Institute of Management - Branch of the Russian Academy of National Economy and \\ Public Administration under the President of the Russian Federation, Department of Mathematical \\ Methods and Information Technologies, 680000, 33 Muravyova-Amursky Street, Khabarovsk, Russia
}

\begin{abstract}
The article analyzes the activities of cultural institutions to provide the population with services in the field of culture and leisure on the example of the regional state budgetary institution of culture Khabarovsk Regional Park named after N.N. Muravyov-Amursky for the period 2018-2020. As a result of the study, the following problems of cultural institutions were identified: inconsistency with modern standards, information and cultural needs of the population of the material and technical base of cultural institutions; insufficient financing of this area and underdeveloped mechanisms for raising funds; personnel problems; low prestige of the professions of the institutions in question; slow introduction of information and communication technologies; carrying out a relatively small number of sports and recreational activities of their total. Based on the analysis, some directions for improving their activities are proposed, namely, the development of concepts of cultural institutions focused on modern conditions with the involvement of popular information and communication technologies, updating approaches to the model of the profession of an employee of a cultural institution, updating the content of activities, possibly with the development of a comprehensive sports and health program designed for various groups of the population, including for persons with disabilities, with involvement of sports unions and associations.
\end{abstract}

\section{Introduction}

Now, the socio-cultural situation is characterized by a number of negative processes that have emerged in the sphere of spiritual life - the loss of spiritual and moral guidelines, alienation from culture and art of children, youth and adults, a significant reduction in the financial security of cultural institutions.

Intellectual, aesthetic, moral education of a person are the main areas to which the activities of cultural institutions are directed. To achieve a versatile upbringing of a person,

\footnotetext{
${ }^{*}$ Corresponding author: pankrateva-sg@,ranepa.ru
} 
special means are used, considering the characteristics of each individual, his/her interests, views, and preferably in his/her free time [1].

The need for constant enrichment of the content of the activities of cultural institutions, methods of its implementation and, the search for new leisure technologies actualizes the problem of improving the activities of cultural institutions for organizing the leisure of the population.

Purpose of the study: to analyze the activities of a cultural institution to provide services to the population in the field of culture and leisure (using the example of the regional state budgetary institution of culture Khabarovsk Regional Park named after N.N. Muravyov-Amursky for the period 2018-2020) and propose ways of its modernization.

\section{Study Methods}

Methodological base of the study: theoretical analysis of special literature, necessary for the study of theoretical, analytical and regulatory frameworks for the activities of parks; studying the experience of cultural institutions in arranging the leisure of the population and an experimental method, including the analysis and generalization of the data obtained. The last two methods are necessary to analyze the activities of the regional park in providing the population with services in the field of culture and leisure.

\section{Results of the Study}

Parks of culture and recreation are the main objects contributing to the rational use of the surrounding nature in the interests of improving the health of residents of their cultural development, the organization of leisure activities [2].

In the conditions of urban life, the population is in constant stress, depression, and shows aggression. Parks contribute to improvement of the emotional, psychological and physiological state of the population [3]. Also, through landscaping and recreation, parks contribute to the improvement of the aesthetic appearance of any city. Today the park is the most complexly organized structure than a few decades ago.

The Park of Culture and Leisure is a cultural institution, the main activity of which is aimed at providing the population with versatile services in the field of culture and leisure. The main goal of the park is to provide the population of adjacent residential areas with the most approximate active recreation area while maintaining deep green space [4].

A modern city park of culture and recreation shall be a comfortable and aesthetically attractive recreational area, with a high level of service and performing several main tasks, the main of which are the following:

- propaganda of national traditions, universal values;

- creating conditions for year-round, good rest and various leisure activities;

- ensuring the safe rest of citizens, the safety of their property;

- provision of cultural recreation to citizens having a rest, as well as all related necessary services [3].

Regional State Budgetary Institution of Culture Khabarovsk Regional Park named after N.N. Muravyov-Amursky (hereinafter - the institution) was created in accordance with the Civil Code of the Russian Federation, Federal Law of 12.01.1996 No.7-FZ" On Non-Profit Organizations", decrees of the Government of the Khabarovsk Territory of 27.10.2010 No. 312-pr "On Regional State and Budgetary Institutions", dated 31.01.2011 No.25-pr "On the Natural Monument of Regional Significance "Central Park of Culture and Leisure", by the decree of the Governor of the Khabarovsk Territory dated 26.01.2017 No. 11 "On the Powers of the Executive Authorities of the Khabarovsk Territory to 
Exercise the Rights of the Owner Property of Regional State Unitary Enterprises and Functions, and Powers of the Founder of Regional State Institutions" [5].

The subject of the institution's activities is implementation of activities aimed at preserving in the natural state a specially protected natural area of regional significance and the provision (presentation) of the population of versatile services in the field of culture and leisure.

The main objectives of the regional park are:

- propaganda of national traditions, universal values;

- creation of conditions for year-round, full-fledged rest and various leisure activities, both for residents of the city and for guests of the regional center;

- ensuring the safe rest of citizens, the safety of their property;

- provision of cultural recreation to citizens having a rest [6].

Over the past few years, the main priority areas of the regional park have been preserved: preservation of cultural heritage, folk art and cultural and leisure activities, professional art, training and retraining of personnel, as well as legal support of the industry. However, let us note the most significant problems.

The material and technical base of the park currently does not meet modern standards, information and cultural needs of the population of the region.

In these conditions, it is more and more difficult for the regional park to compete with other organizations in the struggle for the free time and expenses of citizens and households in the context of the proliferation of mass communication and mass arts, the rapid development of the market for electronic publications and information technologies.

The financing of the industry is one of the central problems of cultural management.

In the era of transition to a market economy, budgetary funding for the cultural sector has fallen dozens of times. Cultural institutions, through the creation of public organizations, the development of targeted programs, the attraction of volunteers, and etc., are trying to overcome the lack of funding, but even these measures do not allow them to provide all their necessary activities [7].

Additionally, cultural institutions are faced with a personnel problem, including the low prestige of the profession of cultural workers [8].

The level of salaries of employees of cultural institutions is one of the lowest among other sectors of the economy. The low level of wages is the result of insufficient financing of cultural institutions, as well as the use of the practice of forced part-time employment (part-time work, part-time work (week), unpaid leave). Due to low wages, lack of benefits, housing programs, the cultural sector loses highly qualified specialists and the staff is aging.

Another urgent problem in the sphere of culture is the very slow introduction of information and communication technologies (hereinafter - the ICT). In the age of ubiquitous informatization, the introduction of ICT plays a huge role. With the help of these technologies, for example, it is possible to digitize cultural and historical values. Consequently, one of the main tasks facing us - preservation of the cultural heritage of various peoples, can be achieved [9].

Despite all the advantages of using information technologies, their implementation in cultural institutions is slow. This can be explained by low funding, the lack of specialized personnel, and low wages.

However, despite the existing problems in accordance with the main priority areas of the regional park in 2018-2020, a set of measures for its development was developed, which was carried out in the following areas:

- protection, preservation and use of objects of cultural heritage of the peoples of the region: immovable monuments of history and culture; development of the museum business; 
- creation of conditions for the activity of creative, sports unions and associations;

- preservation and development of traditional folk culture and folk arts and crafts.

According to the orders of the Ministry of Culture of the Khabarovsk Territory, on the approval of state assignments, in the regional park for the period 2018-2020 the following activities were implemented (Table 1).

Table 1. Data on entertainment and other activities of the regional park.

\begin{tabular}{|c|c|c|c|c|c|c|c|c|c|}
\hline \multirow{3}{*}{ No. } & \multirow{3}{*}{$\begin{array}{c}\text { Indicator } \\
\text { characterizing the } \\
\text { content of public } \\
\text { services }\end{array}$} & \multirow{2}{*}{\multicolumn{2}{|c|}{$\begin{array}{c}\text { Indicator of the } \\
\text { volume of public } \\
\text { services }\end{array}$}} & \multicolumn{6}{|c|}{$\begin{array}{l}\text { The value of the indicator of the } \\
\text { volume of public services }\end{array}$} \\
\hline & & & & \multicolumn{2}{|c|}{2018} & \multicolumn{2}{|c|}{2019} & \multicolumn{2}{|c|}{2020} \\
\hline & & & & $\frac{\text { ్ㅡㄹ }}{2}$ & 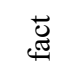 & $\frac{\tilde{t}}{2}$ & 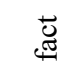 & $\frac{\text { ్ㅕㄴ }}{2}$ & 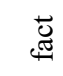 \\
\hline 1 & $\begin{array}{l}\text { Visitor service, } \\
\text { excursions }\end{array}$ & $\begin{array}{l}\text { Number of } \\
\text { visitors }\end{array}$ & People & 958 & 958 & 953 & 953 & 958 & 958 \\
\hline 2 & $\begin{array}{c}\text { Creative (festival, } \\
\text { exhibition, } \\
\text { competition, show) }\end{array}$ & $\begin{array}{l}\text { Number of } \\
\text { events held }\end{array}$ & PCS & 50 & 50 & 45 & 45 & 50 & 50 \\
\hline 3 & $\begin{array}{l}\text { Creation and } \\
\text { preservation of a } \\
\text { diverse species } \\
\text { composition of } \\
\text { plants }\end{array}$ & $\begin{array}{l}\text { Number of } \\
\text { plant species }\end{array}$ & PCS & 67 & 67 & 67 & 67 & 65 & 65 \\
\hline 4 & $\begin{array}{l}\text { Creation of } \\
\text { conditions for } \\
\text { regulated tourism } \\
\text { and recreation, } \\
\text { including the } \\
\text { implementation of } \\
\text { activities in the field } \\
\text { of services to } \\
\text { visitors in protected } \\
\text { areas. }\end{array}$ & $\begin{array}{l}\text { Number of } \\
\text { active } \\
\text { excursion } \\
\text { programs }\end{array}$ & Units & 2 & 2 & 2 & 2 & 2 & 2 \\
\hline 5 & $\begin{array}{c}\text { Recreational } \\
\text { services for } \\
\text { protected areas. }\end{array}$ & $\begin{array}{c}\text { Number of } \\
\text { objects }\end{array}$ & Units & 1 & 1 & 1 & 4 & 1 & 1 \\
\hline
\end{tabular}

Source: compiled by the author on the basis of annexes to the orders of the Ministry of Culture of the Khabarovsk Territory on the approval of state assignments for the period 2018-2020.

Therefore, the state task is being fulfilled $100 \%$ from year to year. However, the number of events does not change, and the actual indicators stand still, or even decrease for some types. So the indicators for the number of visitors and the number of events held in 2018 and 2020 is the same, and in 2019 the indicators decreased. Most likely this trend is associated with bad weather conditions. Further, the values of the indicator "number of plants" in 2018 and 2019 are the same, and in 2020 they are decreasing. The reason for this situation can be called the demolition, sawing of dead trees due to the rejuvenation of plantings in 2019. Replacement of plantings is planned in 2021. The indicator "number of active excursion programs" remains unchanged. The indicator "the number of specially protected natural areas" (hereinafter - SPNA) in the plan remains unchanged, but in 2019, in fact, more than planned was accomplished.

To assess the results of the park's work, we will calculate the efficiency coefficient:

$$
\text { K eff park }=0.4 * \text { Nevents }+0.4 * N \text { numb.v.ex. }+0.2 * N v n b \text {. }
$$


Where Nevents - indicative indicator of the ratio of the actual and planned number of cultural and physical culture and recreational activities; $N$ numb.v.ex. - indicative indicator of the ratio of the actual and planned number of visitors of thematic excursions; Nvnb. - an indicative indicator of the ratio of the actual and planned share of funds from incomegenerating activities in the total volume of financing of the reporting period.

For example, in 2019, the number of activities according to the plan was 45; in fact, 45 were completed. It follows that Nevents is equal to 1 . The number of visitors according to the plan is 953, the actual number of visitors is 953. Hence $\mathrm{N}$ numb.v.ex. is equal to 1.

According to accounting calculations $\mathrm{N}$ vnb. for 2018 is 0.75 , for $2019-0.83$, for 2020 $-0.7[5]$.

Thus, the calculation will be as follows for 2018-2020:

$$
\begin{aligned}
& \mathrm{K} \text { eff park } 2018=0.4 * 1+0.4 * 1+0.2 * 0.75=0.95 \\
& \mathrm{~K} \text { eff park } 2019=0.4 * 1+0.4 * 1+0.2 * 0.83=0.97 \\
& \mathrm{~K} \text { eff park 2020 }=0.4 * 1+0.4 * 1+0.2 * 0.7=0.94
\end{aligned}
$$

It follows from the above calculations that the efficiency factor of the park's activity tends to decrease.

It is worth noting that many of the activities carried out do not fall into the reporting documents, since they are not planned due to the lack of allocated budget funds for these activities. However, the regional park conducts them on its own initiative with the help of volunteers or sponsors in order to attract the population to participate in cultural events, but also to improve the status of the park.

It shall be especially noted that according to Table 1, conducting the sports and recreational activities is not directly included in the number of indicators characterizing the activities of the regional park. This is evidenced by the data on the ongoing activities for 2018-2020. However, as indicated above, this indicator is one of the priority areas of activity of cultural institutions.

Based on the analysis of documents of the Ministry of Culture of the Khabarovsk Territory for 2018-2020 in the regional park the following events are held annually [10].

New Year's performances, theatrical programs, performances and other events during school holidays.

Cheese Fare Week events.

Action "Steps of Health"; classes within the framework of the action "Steps of health" dedicated to the prevention of various diseases (with participation of representatives of the regional diagnostic center Viveya).

Festive events dedicated to the holiday of Spring and Labor on May 1: "Book May"; interactive program "Spring Mood";

Festive events dedicated to the Victory Day in the Great Patriotic War of 1941-1945 (Book parade of Victory in the open air "Victory Salute!"; Solemn laying of an alley with planting of pine seedlings in honor of the Red Banner Amur Flotilla; All-Russian action "Victory Record"; action "Squadron of Heroes"; marathon of choirs "May Waltz", etc.).

Solemn events dedicated to the anniversary of the end of the Second World War.

Events dedicated to the Day of the State Flag of the Russian Federation.

International military music festival "Amur Waves", including the Competition of children's brass bands.

Solemn events dedicated to the Day of the City and the Day of the Region (exhibitions, fairs, fireworks, thematic platforms of regional cultural institutions on the embankment near the stadium named after V.I. Lenin).

Regional stage of the All-Russian Choir Festival (competitive auditions of the participating groups).

Choir concert dedicated to the celebration of the Day of Slavic Literature and Culture. 
Festive programs for children and their parents, dedicated to the International Children's Day: "Creative subbotnik", "Give the sun to childhood", "Bright planet for childhood" arranged and conducted due to cultural institutions.

Summer reading room "Time to read!" (thematic book exhibitions, quizzes, master classes).

Cultural events for the population (exhibitions, concerts, master classes, etc.).

Outreach activities: "Khabarovsk Territory is getting closer" excursion on a motor ship along the Amur river for members of the Leisure Center for the Deafblind; "Ecology and Health. Medicinal plants" (book exhibition, blitz-quiz); open-air book exhibition "Route of A. P. Chekhov across Siberia to Sakhalin"; action "Amur Father. Clean coast - clean water", open-air project" Harvest summer, or how to preserve the summer cottage harvest";

Events dedicated to national traditions: the festival of Korean culture; Tatar folk holiday "Sabantuy"; regional festival "National cuisine"; regional festival of national cultures "We are Russians!", international cultural and educational project in the open air "Day of Dagestan poetry";

Events dedicated to the International Day of Persons with Disabilities.

Youth volleyball competition.

Anniversary events: "Jubilee week" dedicated to the 125th anniversary of the Khabarovsk Regional Museum N.I. named after Grodekov; street action "1917-2017. Lessons from history", the book exhibition" Revolution in Russia: a look through the century" and the blitz-quiz "1917th turning point ... " dedicated to the 100th anniversary of the 1917 revolution in Russia.

Based on the analysis carried out, it can be concluded that the events held do not change significantly from year to year, they are more related to cultural entertainment. We shall note that especially few sports and recreational activities are carried out, and sports events are not held regardless of the season, that is, even in the summer period they either do not exist, or these are isolated cases. However, the availability of sports and recreational activities is one of the main indicators of the activity of a cultural institution. One of the reasons for this situation is the fact that the organization, planning and control of the activities of the regional park is carried out by the founder - the Ministry of Culture of the Khabarovsk Territory. The regional park cannot carry out any activities on its own without agreement with it.

Therefore, there is a need to update the content of the park's work, namely, to create conditions for the activities of sports unions and associations, which is not fully implemented in the regional park.

During the study, the following problems of the regional park were identified:

- obsolescence and lack of material and technical base of the park (buildings, specialized equipment, props, and etc.);

- insufficient financing of the cultural sphere and underdeveloped mechanisms for attracting extra-budgetary funding;

- personnel problems (low prestige of the profession of cultural workers, low wages, problems of attracting young specialists to the industry, as a result, aging of personnel, and etc.);

- extremely slow implementation of modern information technologies and innovations;

- orientation to cultural events, with an insufficient number of sports and recreation.

The identified problems can indirectly entail a deterioration in the quality of life of the population of the region, a decrease in the historical, ecological and spiritual and moral culture of the population of the region, the destruction of the system of cultural values, their replacement by mass pseudo culture that destroys the moral foundations of society, aggravation of social, ethno-confessional problems, increased migration outflow, the emergence of threats to national security. 


\section{Conclusions}

Analysis of the activities of the regional park shows that its main work is aimed at implementing measures to ensure the accessibility of the population of the region to the spiritual values of domestic and world culture, preserving the existing network, and optimizing its activities in the new economic conditions. However, the indicators for the number and types of events do not change, and even tend to decrease. As for sports and recreational activities, there are very few such events, about 5 per year.

The problems highlighted above, due to the existing realities, cannot be solved at once, however, there is a possibility of stopping their development with the aim of subsequent minimization or elimination.

Their step-by-step solution must be carried out in accordance with the directions: development of concepts of cultural institutions in new conditions, improvement of the economic mechanism, updating approaches to the model of the profession of an employee of a cultural institution, updating the content of activities, possibly with development of a comprehensive sports and recreation program designed for various groups of the population, including for persons with disabilities, with the involvement of sports unions and associations.

In addition, in order to improve the activities of the regional park and the state of the regional cultural sphere and ensure its sustainable development in the long term, join the regional project "Sport is the norm of life".

\section{References}

1. C. Bloomfield, Hesitant hopes: How a comprehensive approach to learning impacts on the transition hopes of marginalised young people in an alternative learning programme in regional Australia, Australia British Educational Research Journal, 1 (2020)

2. F. Grivokostopoulou, The effectiveness of embodied pedagogical agents and their impact on students learning in virtual worlds, Computer Engineering and Informatics Department, 4 (2019)

3. N. V. Maksakovskij, Nacional'nye parki v urbanizirovannyh rajonah Rossii (2007)

4. G. Tumanyak, Elektronnoe upravlenie uchastiem $i$ ego vliyanie na kul'turu grazhdanskogo uchastiya, Zenit, 2 (2020)

5. Ustav kraevogo gosudarstvennogo byudzhetnogo uchrezhdeniya kul'tury «Habarovskij kraevoj park imeni N.N. Murav'eva-Amurskogo» (2018)

6. Ministerstvo kul'tury Habarovskogo kraya. Access mode: https://minkult.khabkrai.ru/events/Novosti/1567

7. R. Harrison, Z. Lin, G.Carroll, Simulation modeling in organizational and management research, Academy of management review, 32(4) 2007

8. T. Mikhailova, Social pedagogy and social psychology, Social relation, 11 (2014)

9. S. G. Pankrat'eva, Istoriya razvitiya zakonodatel'stva $v$ sfere sozdaniya $i$ ispol'zovaniya baz dannyh, Vlast' i upravlenie na Vostoke Rossii, 1 (2017)

10. Otchet o vypolnenii gosudarstvennogo zadaniya na 2018-2020 gg. (2019) 